Bartosz Smolik

Uniwersytet Wrocławski

\title{
Współczesne nurty polskiej myśli nacjonalistycznej - próba podziału w aspekcie kategorii „tradycji”
}

DOI: $10.19195 / 1643-0328.21 .4$

Słowa kluczowe: tradycja, nacjonalizm, myśl polityczna, nurty polityczne

\section{Wprowadzenie}

Jednym $\mathrm{z}$ trudniejszych problemów stojących przed badaczem współczesnej myśli politycznej jest dywersyfikacja poszczególnych nurtów w obrębie danego kierunku politycznego. Niniejszy artykuł ma na celu naszkicowanie próby podziału polskiej myśli nacjonalistycznej w aspekcie kategorii „tradycji”. Ze względu na ograniczone ramy opracowania autor skupi się w nim na zarysowaniu samych nurtów, redukując wywody dotyczące metody podziału. Na wstępie warto sprecyzować terminy, które zostały użyte w tytule niniejszej publikacji. Współczesność jest tu rozumiana jako okres rozpoczynający się w 1989 roku. „Tradycja”, dla odróżnienia od rozumienia potocznego ujęta w cudzysłów, jest tu uznawana za rodzaj refleksyjnego i świadomego wyboru dorobku przeszłości dokonywanego w teraźniejszości ${ }^{1}$. Autor wychodzi z założenia, że tak rozumiana „tradycja” może stanowić jeden z głównych — choć oczywiście zarazem jeden z wielu - czynników różnicowania nurtów politycznych we współczesnym polskim nacjonalizmie. W niniejszym artykule zostanie wzięty pod uwagę proces krystalizacji nurtów nacjonalistycznych dokonujący się głównie w okresie poprzedzającym członkostwo Polski w Unii Europejskiej. Nie będą jednak zupełnie pominięte lata późniejsze. Sam termin

${ }^{1}$ Obszerny wykaz literatury dotyczącej fenomenu tradycji znajduje się w: M. Krygier, Tradycja, [w:] Encyklopedia socjologii, t. 4, Warszawa 2002, s. 259. Ponadto: Questions of Traditions, red. M.S. Philips, G. Schochet, Toronto 2004. Ponadto, odnośnie do polskiego ruchu narodowego: B. Grott, Tradycjonalizm i modernizm w polskim nacjonalizmie, [w:] Narodowa Demokracja XIX-XXI wiek (koncepcje - ludzie działalność), red. T. Sikorski, A. Wątor, Szczecin 2008; E. Maj, Tradycja w myśli narodowej i narodowo-katolickiej w Polsce po 1989 roku, [w:] Marzyciele i realiści. O roli tradycji w Polskiej myśli politycznej od upadku powstania styczniowego do XXI wieku, red. T. Sikorski, A. Wątor, Szczecin 2009. 
„nacjonalizm” to szeroka naukowa kategoria opisowa, nie zaś wartościujące określenie publicystyczne o negatywnej konotacji.

Podział, który proponuje autor, ma na celu wykorzystanie wspomnianej „tradycji” jako kategorii różnicującej, a zarazem nadającej genetyczną tożsamość poszczególnym nurtom nacjonalistycznym. Polska myśl nacjonalistyczna doczekała się już kilku prób dywersyfikacji, czego przykładami mogą być prace Ewy Maj oraz Bogumiła Grotta. W pierwszym wypadku wyznaczony został podział na myśl narodową i nacjonalistyczną, w drugim dokonano wyodrębnienia nacjonalizmu chrześcijańskiego, laickiego i pogańskiego ${ }^{2}$. Ewa Maj dokonała także bardziej szczegółowej dywersyfikacji polskiego nacjonalizmu po 1989 roku, wyodrębniając nacjonalizm liberalny, narodowo-katolicki, narodowo-ludowy, narodowo-radykalny, słowiański i tradycjonalistyczny ${ }^{3}$.

Specyfika nacjonalizmu i współczesnej myśli nacjonalistycznej po 1989 roku wpisuje się w ogólną tendencję, zauważaną przez teoretyków nacjonalizmu oraz polskich badaczy myśli nacjonalistycznej, polegającą na wzrastającym tradycjonalizmie i zainteresowaniu przeszłością. Bardzo często współczesny nacjonalizm odwołuje się do przeszłości Polski, w tym zwłaszcza ruchu narodowego. Dlatego też można przyjąć, że jest to specyfika zgodna z tendencją zarysowaną już przez klasyka teorii nacjonalizmu Carltona Hayesa, który w swoim ujęciu diachronicznym nacjonalizmów nowoczesnych uwidacznia wzrastające zainteresowanie przeszłością, co widać zwłaszcza w wyróżnionych przez niego nacjonalizmach - tradycyjnym i integralnym, jak również o wiele wcześniejszym humanitarnym ${ }^{4}$. Analogiczne zjawisko występujące wśród nacjonalizmów zauważali również Hans Kohn i Ernest Gellner5. Także badacze polskiej myśli politycznej niejednokrotnie wskazywali na bardziej lub mniej udane próby kontynuacji przedwojennej myśli nacjonalistycznej ${ }^{6}$. Współczesny nacjonalizm na obecnym etapie swojego rozwoju w coraz

2 E. Maj, Myśl narodowa i nacjonalistyczna, [w:] Myśl polityczna w Polsce po 1989 roku. Wybrane nurty ideowe, red. E. Maj, A. Wójcik, Lublin 2008, s. 114-116; B. Grott, Nacjonalizm czy nacjonalizmy (zamiast wstępu), [w:] Nacjonalizm czy nacjonalizmy? Funkcja wartości chrześcijańskich, świeckich i neopogańskich $w$ ksztaltowaniu idei nacjonalistycznych, red. idem, Kraków 2006, s. 10-11. Wyodrębnienia nurtu neoendeckiego, mając na myśli głównie ugrupowania „odwołujące się bezpośrednio do tradycji endeckiej”, dokonał także J. Tomasiewicz. Zob. idem, Ugrupowania neoendeckie w III Rzeczypospolitej, Toruń 2003, s. $9-10$.

${ }^{3}$ Zdaniem autorki w tym okresie poszczególne nurty ideowe cechował odmienny pogląd w odniesieniu do kilku kwestii. Wymienia ona wśród nich takie sprawy, jak: 1) ocena historii Polski Ludowej, 2) preferowany system polityczny, 3) prywatyzacja majątku narodowego, 4) niepolska ludność mieszkająca w granicach państwa polskiego, 5) pozycja Kościoła rzymskokatolickiego, 6) model integracji Polski z Unią Europejską. E. Maj, Wielonurtowość myśli nacjonalistycznej w Polsce współczesnej, [w:] Idee w procesie kształtowania wspótczesnej rzeczywistości polskiej. Nacjonalizm, red. E. Maj, M. Mikołajczak, M. Śliwa, Kraków 2010, s. $81-82,85$.

${ }^{4}$ C.J.H. Hayes, The Historical Evolution of Modern Nationalism, New York 1931, s. 29, 129, 165, passim.

${ }^{5} \mathrm{H}$. Kohn, The Idea of Nationalism. A Study in Its Origins and Background, New Brunswick 2005, s. 229-331; E. Gellner, Narody i nacjonalizm, Warszawa 1991, s. 79.

${ }^{6}$ Dotyczy to zarówno środowisk i ugrupowań zaliczanych przez Grotta do nacjonalizmu chrześcijańskiego, jak i neopogańskiego, a także zaliczonych przez Maj do myśli narodowej i nacjonalistycznej. Wśród tych ostatnich pojawiają się ugrupowania z nurtu narodowo-radykalnego. C. Maj, E. Maj, Narodowe ugrupowania polityczne w Polsce 1989-2001, Lublin 2007, s. 9, 12, 13, 49, 95, 158 n.; B. Grott, Religia, cywilizacja, 
wyższym stopniu upodabnia się do konserwatyzmu, w którym z kolei zwraca się uwagę na habitualizację zachowań ludzkich oraz związane z tym funkcje normotwórcze ${ }^{7}$.

\section{Główne cechy fenomenu „tradycji”}

W opinii autorów zajmujących się fenomenem „tradycji”, przede wszystkim takich, jak: Jerzy Szacki, Anthony Giddens, należy oddzielić od siebie „tradycję” rozumianą jako świadomy wybór przeszłości od bezrefleksyjnego „dziedzictwa” lub „rytuału”8. Zgłoszone przez Szackiego „dziedzictwo”, jak też jego odpowiedniki o innych nazwach, przejmowane są w sposób całościowy i zarazem bezrefleksyjny. Może też ono być rozumiane analogicznie do zauważanej przez Feliksa Konecznego „tradycji biernej”. W niej nie dokonują się zmiany ani innowacje. Tego samego nie można powiedzieć o „tradycji”, która musi znaleźć akceptację w teraźniejszości ${ }^{9}$. Jak stwierdza socjolog religii Danièle Hervieu-Léger, składniki przeszłości muszą mieć „autorytet w teraźniejszości”. Nie jest zatem ważna odległość w czasie dzieląca współczesność od czasów genezy danej „tradycji”, lecz jej ciągłość i zdolności innowacyjne i reinterpretacyjne ${ }^{10}$.

Zdaniem zajmującego się tą problematyką socjologa Edwarda Shilsa oraz wspomnianego Giddensa „tradycja” podlega nie tylko wyborowi, lecz także innowacjom. Uwidacznia się tu rola osób odpowiedzialnych za transmisję międzypokoleniową, tak zwanych strażników „tradycji”. Osoby te pragną nie tylko przekazać dorobek przeszłości następnym generacjom, lecz bardzo często również dokonać jego konkretyzacji i syntetyzacji oraz wyeliminować tkwiące w nim niespójności ${ }^{11}$. Narzucająca się w tym miejscu analogia do doktryn religijnych, na co wskazuje Shils, musi mieć jednak pewne granice, myśl polityczna ma bowiem nieco inną specyfikę i charakteryzuje się znacznie większą efemerycznością związaną z bieżącą sytuacją polityczną.

Strażnicy „tradycji” myśli politycznej w pierwszej kolejności są odpowiedzialni za kultywowanie aksjologicznych pryncypiów tej myśli i przekazanie ich następnym pokole-

rozwój. Wokół idei Jana Stachniuka, Kraków 2003, s. 296-310; A. Meller, Myśl polityczna Narodowego Odrodzenia Polski w latach 1994-2004 - epigoństwo czy twórcze rozwinięcie dziedzictwa międzywojennych narodowych radykałów?, [w:] Epigoństwo czy twórcza ciagłość? Ideowe dziedzictwo głównych nutów politycznych Drugiej Rzeczypospolitej po zakończeniu II wojny światowej, red. E. Krasucki, T. Sikorski, A. Wątor, Toruń 2011, s. 140-145, 150-159.

${ }^{7} \mathrm{Na}$ takie postrzeganie przez konserwatystów życia społecznego oraz roli „tradycji” zwracają uwagę między innymi autorzy publikowanych w Polsce syntez dotyczących konserwatyzmu. Zob. R. Scrurton, Co znaczy konserwatyzm, Poznań 2002, s. 59-65; B. Miner, Zwięzła encyklopedia konserwatyzmu, Poznań 1999, s. 259-260.

8 J. Szacki, Tradycja. Wydanie II rozszerzone, Warszawa 2011, s. 141, 158; A. Giddens, Życie w społeczeństwie posttradycyjnym, [w:] U. Beck, A. Giddens, S. Lash, Modernizacja refleksyjna, Warszawa 2009, s. 89.

9 F. Koneczny, Polskie logos a ethos, t. I, Poznań 1921, s. 33-34.

10 D. Hervieu-Léger, Religia jako pamięć, Kraków 2007, s. 125.

11 E. Shils, Tradition, „Comparative Studies in Society and History” 1971, nr 2, s. 145, 151, 154, 155; A. Giddens, op. cit., s. 90. 
niom. Mogą oni jednak być zarazem progresywistycznymi modernizatorami dostosowującymi „tradycję" własnego ruchu politycznego do często zupełnie nowej rzeczywistości politycznej. Z jednej strony kultywują zatem kanoniczne elementy „tradycji”, odpowiadają za jej adaptację przez następne pokolenia, $\mathrm{z}$ drugiej eliminują to, co w ich opinii stało się ewidentnym anachronizmem. Tym samym spełniają funkcje: adaptacyjną i innowacyjną. Należy zaznaczyć, że nie wszyscy strażnicy „tradycji” dostrzegają potrzebę jej modernizacji. Równie dobrze mogą poprzestać na staraniach o jej adaptację przez następne pokolenia, ograniczając innowację do minimum. Także oni dokonują wyboru dorobku przeszłości, nie zawsze jest to jednak wybór zmierzający ku eliminacji składników uznawanych powszechnie za zbędne anachronizmy. Warto tu na chwilę powrócić do Szackiego, który stwierdza, że upowszechnianie „tradycji” polega przede wszystkim na propagowaniu pewnych wartości i wzorów do naśladowania. Problem tradycji to także problem celów, którym podporządkowuje się czyjąś działalność oraz hierarchię wartości, jaką uznaje się za godną propagowania ${ }^{12}$. Stwierdzenie, że jakaś „tradycja” jest dobra, zależy zatem od konstatacji jej aktualnej funkcji wychowawczej. Taką też funkcję można by przypisać strażnikom.

Do strażników „tradycji” nacjonalistycznej w rozmaitych nurtach zaliczają się w pierwszej kolejności takie postacie, jak: Jędrzej Giertych, Wojciech Wasiutyński, Wiesław Chrzanowski, Antoni Wacyk, a zatem osoby mające trudny do przecenienia wpływ na współczesną myśl polityczną. W drugiej kolejności wymienić należy również seniorów ruchu narodowego, jak: Jan Matłachowski, Napoleon Siemaszko, Leon Mirecki, Bronisław Ekert i inni. Ich wpływ na obszar myśli politycznej był mniejszy, podtrzymywali jednak „tradycję" organizacyjną ruchu narodowego. Polska specyfika ich działalności polegała na tym, że przekazywali „tradycję”, często niemal odkrywaną na nowo przez młode pokolenia, po latach represji ze strony władz PRL.

„Tradycję" polskiego nacjonalizmu trudno ograniczyć do samej tylko myśli politycznej, nawet zespolonej z filozofią polityczną. Można odnaleźć znacznie więcej obszarów wybiórczej przeszłości rzutujących na kształt współczesnego polskiego nacjonalizmu. Chodzi tu o historię szeroko pojętego ruchu narodowego (łącznie z działalnością kulturalną, literacką i edytorską, krytycznoliteracką), ogólną interpretację dziejów Polski i świata, martyrologię okresu II wojny światowej oraz Polski Ludowej (czyt. „żołnierze wyklęci"). Nie należy też zapominać o takich obszarach komunikowania politycznego, jak endecka symbolika graficzna, rytuały, pieśni, hasła i powitania obecne w okresie międzywojennym lub wcześniejszym. One również podlegają refleksyjnemu wyborowi. Między wspomnianymi obszarami „tradycji” zachodzą określone interakcje. Myśl polityczną trudno rozpatrywać jako układ hermetyczny i wyizolowany od reszty. Jak zauważa Ewa Maj, świat polityki raczej nie funkcjonuje bez umownych konotacji, symboliki, figuratywności, ceremonii i rytuałów politycznych ${ }^{13}$. Najważniejszym obszarem pozostaje jednak myśl polityczna, bez której trudno mówić o jakimkolwiek nacjonalizmie. Myśl odgrywa w nim rolę centralną i bez niej można mówić co najwyżej o patriotyzmie, etnocentryzmie, ksenofobii lub szowinizmie.

12 J. Szacki, op. cit., s. 145, 149.

13 E. Maj, Komunikowanie polityczne Narodowej Demokracji 1918-1939, Lublin 2010, s. 341. 


\section{Nurt neoendecki}

Pierwszym z nurtów, który zostanie wyróżniony przez zastosowanie powyższych kryteriów, jest stosunkowo wyrazisty nurt neoendecki. Szczególnie dobrze rozwijał się on na początku lat 90. Charakteryzuje go kilka istotnych elementów „tradycji”, wśród których można wymienić:

1. Wybiórcze podejście do „ojców założycieli” endecji - gloryfikacja myśli R. Dmowskiego, duża atencja w stosunku do myśli Jana L. Popławskiego oraz ograniczenie do niezbędnego minimum pamięci o myśli politycznej Zygmunta Balickiego ${ }^{14}$.

2. Częste i otwarte nawiązywanie do dorobku naukowego Feliksa Konecznego - jako przykład „tradycji” wzbogacającej dotychczasowy kanon i wykraczającej poza dotychczasowe endeckie „dziedzictwo". W okresie międzywojennym jego popularność wśród endecji była bowiem dość ograniczona (jest to zatem komponent innowacyjny, dopisany do „tradycji” już w okresie powojennym).

3. Bardziej lub mniej otwarte nawiązywanie do twórczości Jędrzeja Giertycha (książki, listy otwarte, broszury). Twórczość Giertycha w konstytuowaniu tego nurtu odgrywa podwójną rolę. Dokonuje selekcji „dziedzictwa” i eliminacji zbędnych treści oraz przekazu wybranej tą drogą "tradycji” kolejnym generacjom narodowców. Należy do tego dodać również istotny i bardzo szeroki w jego twórczości wątek publicystyki historycznej i jego wpływ na obraz dziejów Polski, podobnie jak i swoistą metodologię ich postrzegania. Giertych jest zatem odpowiedzialny za „transmisję” szeroko pojętej myśli politycznej i wzbogacenie nią "tradycji” tego nurtu. Pełni on zatem funkcję strażnika „tradycji” strzegącego kanonu, ale zarazem też dokonującego, istotnych innowacji. Stosunek do twórczości Giertycha oraz jego oglądu dziejów nie był oczywiście jednoznacznie bezkrytyczny. Stawał się przedmiotem licznych polemik w obrębie tego nurtu. Utrudniał także finalizację licznych inicjatyw zjednoczeniowych ${ }^{15}$. Twórczość Giertycha wśród środowisk narodowych odgrywała trudną do przecenienia rolę jeszcze w okresie PRL ${ }^{16}$.

4. Antyniemieckość i przez długi okres na ogół przychylny lub neutralny stosunek wobec Rosji - znamienna wydaje się ewolucja poglądów Romana Giertycha i Młodzieży Wszechpolskiej - jeszcze w pierwszej połowie lat 90. postulowano utrzymywanie

14 Gloryfikowanie postaci i myśli politycznej Dmowskiego jest widoczne chociażby w formie tytułów publikacji dotyczących zagadnień historycznych i geopolitycznych. Zob. M. Giertych, Dmowski czy Piłsudski?, Wrocław 1995; J. Engelgard, Testament Dmowskiego. Niemcy - Rosja - Polska, Warszawa 1996.

15 Przykładem tego może być polemika między „Słowem Narodowym” a „Głosem Narodu”, dotycząca między innymi postaci i twórczości Jędrzeja Giertycha. J.L. Majewski, Normalność i dewiacja w ruchu narodowym, „Głos Narodu” 1990, nr 4, s. 8. Artykuł był reakcją na tekst P. Piesiewicza zamieszczony w „Słowie Narodowym", w którym wyrażał się on z szacunkiem o J. Giertychu, z zastrzeżeniem jednak, że nie zamierza akceptować wszystkich jego poglądów. Piesiewicz z kolei reagował na niepochlebną wypowiedź W. Wasiutyńskiego o poglądach politycznych Giertycha przejmowanych przez krajowych neoendeków. Zob. P. Piesiewicz, $O$ nurtach $w$ Ruchu Narodowym, politycznych dewiacjach, propagandowych manipulacjach $i$ antyendeckich obsesjach, „Słowo Narodowe” 1989, nr 5-6, s. 77-82.

16 M.J. Chodakiewicz, J. Mysiakowska-Muszyńska, W.J. Muszyński, Polska dla Polaków! Kim byli i sa polscy narodowcy, Poznań 2015, s. 384, 408. 
strategicznej bliskości z Federacją Rosyjską na zasadzie analogicznej do special partnerships między USA a Wielką Brytanią ${ }^{17}$.

5. Nawiązywanie do „tradycji” myśli okresu dwudziestolecia międzywojennego, w tym zwłaszcza wzrastającego pozytywnego stosunku obozu narodowego do Kościoła katolickiego - w okresie dwudziestolecia międzywojennego związane były z tym próby syntetycznego łączenia myśli nacjonalistycznej z doktryną Kościoła katolickiego. Kościół jest uznawany za potencjalnego sojusznika w walce $\mathrm{z}$ tendencjami i ruchami lewicowymi, lewackimi i liberalizmem. Podobnie jak w okresie międzywojennym pojawia się jednak umiarkowana krytyka Kościoła instytucjonalnego, głównie odnośnie do spraw politycznych, w tym zwłaszcza stosunku do procesu integracji europejskiej ${ }^{18}$. Ponadto neoendecy z dużą i na ogół nieskrywaną niechęcią spoglądają na postępujące przemiany posoborowe ${ }^{19}$.

Organizacyjnymi reprezentantami neoendecji są takie ugrupowania, jak: SN „Senioralne", Stronnictwo Narodowo-Demokratyczne, Młodzież Wszechpolska (w okresie dominacji w niej Romana Giertycha), Stronnictwo Narodowe „Szczerbiec”, w dużej części także Liga Polskich Rodzin — w różnych okresach jej istnienia. Nurt ten jest reprezentowany również przez środowisko tygodnika „Myśl Polska”.

\section{Nurt katolicko-narodowy}

O wiele mniejszą wyrazistość wykazuje natomiast znacznie szerszy i bardziej pojemny nurt katolicko-narodowy. W jego obrębie znajdują się bowiem nie tylko analogie do przedwojennej endecji, lecz także innych historycznych nurtów politycznych, które mają związek z posoborowym magisterium Kościoła rzymskokatolickiego. Chodzi tu zwłaszcza o ruch ludowy. Do najważniejszych elementów „tradycji” można zatem zaliczyć takie cechy, jak:

1. Częste nawiązywanie do myśli i wypowiedzi hierarchów i teologów polskiego Kościoła rzymskokatolickiego w przeciwieństwie do „ojców założycieli” endecji. Nurt katolicko-narodowy charakteryzuje się bardziej ograniczonym nawiązywaniem do endeckiej „tradycji”, która jest w nim obecna czasami na równi z „tradycją” myśli ruchu ludowego.

17 R. Giertych, Kontrrewolucja młodych, Warszawa 1994, s. 93-94.

18 Niezależnie od proliberalnych biskupów, głównie w osobach abpa Józefa Życińskiego i bpa Tadeusza Pieronka, krytyka z czasem objęła również cały Episkopat, nie omijając też samego prymasa Józefa Glempa. J. Dmowski, W kręgu zdrady i złudzeń, „Nowa Myśl Polska” 2002, nr 46, s. 8; M. Bednarz, Zdrada kleryków, „Myśl Polska” 2001, nr 21, s. 15; idem, Kwestia tożsamości politycznej, „Nowa Myśl Polska” 2002, nr 1-2, s. 14; M. Giertych, Katolik w polityce, „Nowa Myśl Polska” 2002, nr 3, s. 8.

Szerzej na temat rozbieżności między ND a Kościołem rzymskokatolickim w okresie międzywojennym, zwłaszcza odnośnie do kwestii narodowościowych, zob. E. Maj, Związek Ludowo-Narodowy (1918-1928) wobec religii i Kościoła rzymskokatolickiego, „Studia Historyczne” 1993, z. 3.

19 B. Kowalski, Encyklika podstaw cywilizacji, „Myśl Polska” 1993, nr 20, s. 1. W przypadku SN „Szczerbiec" przykładem tego może być petycja skierowania do Jana Pawła II o powrót do tradycyjnej mszy świętej według rytu trydenckiego. Uznawano zarazem obrządek mszy świętej wprowadzony przez Pawła VI „Za błędny", Pracownia Informacji i Dokumentacji Naukowej, 14570/97/821. 
Natomiast szeroko i otwarcie sięga on do magisterium prymasa Stefana Wyszyńskiego, w tym zwłaszcza jego dorobku dotyczącego narodu oraz związków narodu z Kościołem rzymskokatolickim ${ }^{20}$. Przedstawiciele tego nurtu swoją dotychczasową „tradycję” myśli politycznej wzbogacają również o wypowiedzi Jana Pawła II dotyczące cech i praw narodu $^{21}$. W nurcie tym obecne są także wpływy pism o. Jacka Woronieckiego i o. prof. Mieczysława Krąpca. Rzadko natomiast otwarcie nawiązuje się do dorobku Jędrzeja Giertycha.

2. Wyraźne podkreślanie personalizmu chrześcijańskiego i otwarcie na posoborowe magisterium Kościoła. Konsekwencją tego jest silnie eksponowany personalizm chrześcijański, a także nawiązywanie w wyższym stopniu do encyklik i magisterium posoborowego w przeciwieństwie do przedsoborowego. Przedstawiciele tego nurtu wyrażają na ogół pozytywny stosunek do przemian zachodzących w Kościele, aczkolwiek zastrzegają, że nie powinny być one wprowadzane zbyt szybko ${ }^{22}$. Krytykują także niektóre przejawy progresizmu ${ }^{23}$.

3. Częste nawiązywanie do teorii cywilizacji Feliksa Konecznego. Podobnie jak w przypadku nurtu neoendeckiego Koneczny wzbogaca „tradycję” tego nurtu w sposób wtórny, czyli stosunkowo późno. Jego teoria cywilizacji znajduje szerokie zastosowanie w publicystyce katolicko-narodowej, a także w teoriach dotyczących przyszłości Euro$\mathrm{py}^{24}$. Koneczny pojawia się w tym nurcie szczególnie często w kontekście rozważań nad procesem integracji europejskiej.

4. Silny antykomunizm połączony z bogato uzasadnioną aksjologiczne krytyką ideowych spadkobierców oświecenia. Komunizm jest często porównywany z liberalizmem, postmodernizmem i globalizmem jako kierunek o podobnym przesłaniu i podłożu ideologicznym. Brak w tym nurcie doszukiwania się pozytywów PRL oraz związanych z tym haseł „sprawiedliwej oceny” tej epoki. Często wskazuje się zatem negatywne skutki PRL rzutujące na bieżącą kondycję społeczeństwa polskiego ${ }^{25}$.

20 C. Bloch, Kardynał Wyszyński, obrońca Polski, Narodu i Kościoła, „Nowy Przegląd Wszechpolski” 1994, nr 1, s. 4-6; A. Sztandera, Prymas kontra lewica, „Nowy Przegląd Wszechpolski” 1994, nr 1, s. 11-12; W. Bojarski, Nowa strategia dla Polski, „Nasz Dziennik” 2004, nr 220, s. 18-19; P. Jaroszyński, Kim jesteśmy, Lublin 2001, s. 96-98; J.M. Jackowski, Bitwa o prawdę, t. III, Warszawa 1997, s. 5 n. oraz wiele innych pozycji.

21 A. Maryniarczyk, Narody dobrem społeczeństwa czy zagrożeniem?, „Nasz Dziennik” 2000, nr 164, s. 14.

22 W. Świątkiewicz, Sobór dwudziestego wieku, „Nasz Dziennik” 1998, nr 263, s. 6.

23 Przykładem tego może być bogata twórczość publicystyczna Z. Żmigrodzkiego, w której nie ma jednak zarazem proendeckich sentymentów. Zob. Z. Żmigrodzki, Meandry nowej wiary, czyli inwazja katolewicy, Komorów 1998; idem, Akcje antynarodowe, Wrocław 2005.

24 P. Skrzydlewski, Wielość cywilizacji a Unia Europejska, „Nasz Dziennik” 1998, nr 249, s. 11; M. Ryba, Cywilizacyjne modele jednoczenia Europy, „Nasz Dziennik” 1999, nr 84, s. 12; idem, O cywilizacjach, „Nasz Dziennik” 1999, nr 90, s. 13; M. Węgrzyn, Historia - mistrzyni polityki polskiej (cz. 3), „Nasz Dziennik” 2000, nr 188, s. 20; P. Jaroszyński, Polska bez ziemi?, „Nasz Dziennik” 2001, nr 26, s. 11-12; R. Brzózka, Narodowa obsesja liberałów, „Nasz Dziennik” 2002, nr 162, s. 19, passim.

25 J. Gołębiowski, W obronie wiary, polskości i własności, „Nowy Przegląd Wszechpolski” 1995, nr 4-5, s. 1; P. Jaroszyński, Czy koniec cenzury? „Nasz Dziennik” 1998, nr 222, s. 9; idem, Suwerenność nie jest przeżytkiem!, Lublin 2000, s. 136. 
5. Antyniemieckość jest eksponowana na równi z antyrosyjskością. Brakuje geopolitycznego uzasadnienia konieczności utrzymywania bliższych relacji z Moskwą niż z Berlinem. Jest to wyraźna różnica w stosunku do nurtu neoendeckiego, świadcząca o odmiennym podłożu doktrynalnym.

Do organizacyjnych reprezentantów tego nurtu autor zalicza takie ugrupowania i środowiska, jak: Stronnictwo Ludowo-Narodowe/Przymierze Ludowo-Narodowe, Klub Myśl dla Polski, w dużej części środowiska skupione wokół Radia Maryja, dużą część środowisk wchodzących do niedawna w skład Ligii Polskich Rodzin w początkowym okresie jej funkcjonowania. Lista ta jest oczywiście o wiele dłuższa, lecz kryterium organizacyjne nie jest w tym wypadku najistotniejsze i może stanowić co najwyżej jedną ze wskazówek. Posoborowe magisterium Kościoła niewątpliwie wpływa łagodząco na retorykę ich wypowiedzi.

\section{Nurt narodowo-radykalny}

Oba pokrótce opisane nurty w przybliżeniu mieszczą się w obrębie scharakteryzowanej przez Ewę Maj myśli narodowej. Inną jakość stanowi natomiast nurt narodowo-radykalny, który z kolei w dużej części pokrywa się z opisaną przez autorkę myślą nacjonalistyczną. W tym wypadku trudno mówić o łagodności retoryki, gdyż nurt ten otwarcie nawiązuje do „tradycji” myśli oraz organizacji i symboliki takich podmiotów, jak przedwojenny Obóz Narodowo-Radykalny z 1934 roku, a także jego obydwu mutacji w postaci ONR „Falanga” i ONR „ABC”26. Nurt ten utożsamia się również z częścią myśli politycznej ND, w tym zwłaszcza myślą Dmowskiego. Niektóre środowiska z tego nurtu chętnie sięgają do myśli i tradycji międzywojennych nacjonalistycznych ekstremistów z innych krajów z takich organizacji, jak: rumuńska Żelazna Gwardia, hiszpańska Falanga czy też francuski Ognisty Krzyż ${ }^{27}$. Ponadto do głównych elementów tradycji można zaliczyć:

1. Silny antydemokratyzm lub przynajmniej sceptycyzm wobec demokracji i antysystemowość - jest rzeczą charakterystyczną dla nurtu narodowo-radykalnego ${ }^{28}$. Można się w tym doszukać elementów kontynuacji przedwojennej ideologii ONR, w której często pojawiają się ataki na rządzącą sanację i stworzony przez nią system.

${ }^{26}$ Deklaracja Ideowo-Programowa Ofensywy Narodowo-Radykalnej, „Błyskawica” 1993, nr 8, s. 22; Powstanie Frontu Narodowo-Radykalnego, „Sztafeta” 1994, nr 1, s. 3; S. Dawidowski, Wprowadzenie w program i założenia ideowe FNR-ONR, „Sztafeta” 1995, nr 1/3, s. 2-3. Autor tego artykułu wielokrotnie używa w nim cytatów zaczerpniętych z przedwojennego ONR; również zdaniem liderów NOP wypowiadających się na ten temat już w pierwszej połowie lat 90 . duch panujący w ich ruchu miał „wywodzić się bezpośrednio z ONR-u”. 60 rocznica Obozu Narodowo-Radykalnego, „Awangarda Narodowa” 1994, nr 5, s. IV.

27 B. Kozieł, Legenda ,żelaznej gwardii”, „Awangarda Narodowa” 1994, nr 6, s. IV-V; T. Greniuch, Droga nacjonalisty, Opole 2013, s. 15. Ma to miejsce zwłaszcza w przypadku NOP zob. A. Meller, op. cit., s. 154.

28 A. Gmurczyk, Przekleństwo demokracji, „Szczerbiec” 1994, nr 10, s. 3; idem, Zorganizowany radykalizm, „Szczerbiec” 1995, nr 6-7, s. 3; T. Sikorski, Miejsce antydemokratyzmu w publicystyce politycznej Narodowego Odrodzenia Polski, [w:] Narodowa Demokracja XIX-XX wiek, s. 536. Również obecni liderzy Obozu Narodowo-Radykalnego zgłaszają swój sceptycyzm wobec demokracji; zob. R. Winnicki et al., Kto się boi ruchu narodowego, Warszawa 2013, s. 92. 
2. Aktywizm w formie rewolucyjnej - chętne i częste manifestowanie wiecowych form uprawiania polityki ${ }^{29}$. Podkreślanie zarazem w ten sposób swojej odmienności w dziedzinie myśli oraz form działalności w stosunku do starszych generacji narodowców ${ }^{30}$. Jest to jednocześnie nawiązanie do obecnego w przedwojennym ONR hasła kreowania nowego człowieka - aktywnego działacza ${ }^{31}$.

3. Alternatywne formy ekonomii jako poszukiwanie rodzaju trzeciej drogi - popularne w tym nurcie są: korporacjonizm i dystrybucjonizm, a zatem doktryny podzielane przez ideologów ONR (Jan Mosdorf) lub zbliżonych do ONR (Adam Doboszyński). Narodowi radykałowie poszukują również nowych form uwłaszczenia narodu ${ }^{32}$. Kwestie gospodarcze dzielą narodowych radykałów z NOP i Ruchu Narodowego, zazwyczaj nie są oni jednak zwolennikami neoliberalnej nieograniczoności wolnego rynku ${ }^{33}$.

4. Spóźnione zainteresowanie historiozofią Feliksa Konecznego. Początkowo w nurcie tym nie ma zbyt częstych odwołań do historiozofii Konecznego, czym wyraźnie różni się on od obydwu powyżej zaprezentowanych nurtów. Przykładem tego może być ideologia $\mathrm{NOP}^{34}$. Sporadyczne zainteresowanie nim przejawia obecny ONR.

5. Gloryfikacja „żołnierzy wyklętych”. Została ona zapoczątkowana w tym nurcie. Stała się nowym składnikiem jego „tradycji”, silnie podkreślanym przez narodowych radykałów. Budzi wątpliwości wśród niektórych przedstawicieli innych nurtów nacjonalistycznych ${ }^{35}$.

29 Dlaczego warto wstapić do ONR, http://www.onr.com.pl/dlaczego.html (dostęp: 13.02.2014); O nas, http://www.onr.com.pl/index.html (dostęp: 13.02.2014).

${ }^{30} \mathrm{~W}$ ostatnich kilku latach symptomatyczny wydaje się spór pomiędzy P. Holocherem a M. Giertychem odnośnie do obecnej linii programowej Ruchu Narodowego. P. Holocher, Giertychów logika przedziwna, http://prawy.pl/index.php?option=com_content\&view=article\&id=2333:giertychow-logika-przedziwna\&c atid=58:felieton (dostęp: 9.03.2013) por. 11 listopada, „Opoka w Kraju” 2012, nr 80, s. 3.

31 Idea ta znalazła swoją współczesną kontynuację w postaci formuły „politycznego żołnierza” propagowanego przez NOP. K. Sitnik, Zasady rewolucji narodowej, „Szczerbiec” 1994, nr 11, s. 11.

32 Szerzej na temat dystrybucjonistycznych inspiracji w okresie międzywojennym w środowiskach narodowo-radykalnych zob. R. Łętocha, Idee dystrybucjonistyczne w poglądach społeczno-gospodarczych młodego pokolenia obozu narodowego, [w:] Europejskie inspiracje myśli politycznej w Polsce od XIX wieku. Recepcja - kontynuacja - interpretacja, red. E. Maj et al., Lublin 2013, s. 267, 272-273. Większe zainteresowanie dystrybucjonizmem i korporacjonizmem pojawiło się w okresie lat 90. wśród ideologów NOP. Na przykład M. Wojciechowski, Podstawy dystrybucjonizmu, „Szczerbiec” 1994, nr 10, s. 7-8; A. Gmurczyk, Podstawy ustroju korporacyjnego, „Szczerbiec” 1994, nr 11, s. 10. Inne środowiska kontynuujące „tradycję" ONR opowiadały się $\mathrm{w}$ tym okresie za upowszechnieniem własności. Były to zatem postulaty korespondujące $\mathrm{z}$ dystrybutywizmem. Zob. Wprowadzenie w program i założenia ideowe FNR-ONR, s. 2-3. S. Dawidowski, Wstęp do ekonomii narodowej, „Ognisty Krzyż. Pismo Obozu Narodowo-Radykalnego” 1995, nr 1, s. VII. Podobne pomysły nie pojawiają się jeszcze w programie Ofensywy Narodowo-Radykalnej. Zob. Deklaracja Ideowo-Programowa Ofensywy Narodowo-Radykalnej, „Błyskawica” 1993, nr 8, s. 23.

33 Warto pamiętać, że wśród liderów RN znajdują się dawni członkowie i sympatycy Unii Polityki Realnej.

34 Ideolodzy NOP w latach 90. i na początku 2000 roku najczęściej pomijali twórczość F. Konecznego, poszukując inspiracji swoich konstrukcji historiozoficznych w twórczości ks. M. Poradowskiego. M. Strutyński, Religia i naród. Inspiracje katolickie w myśli ruchu narodowego w Polsce współczesnej (1989-2001), Kraków 2006, s. 405.

35 J. Engelgard, Mit „żołnierzy wyklętych” i rzeczywistość, „Myśl.pl” 2008, nr 9, s. 75-78; M. Motas, Problem „wyklętych”, „Myśl Polska” 2013, nr 11-12, s. 18. 
W obrębie „tradycji” można również umiejscowić silny i szeroko pojęty antykomu$n^{n i z m}{ }^{36}$. Obecny w ideologii przedwojennych ONR-ów przybiera postać nie tylko rozliczeń z PRL, lecz także walki z prawdziwymi lub domniemanymi pozostałościami ustrojowymi Polski Ludowej. Obecnie często przyjmują one nazwę „Republiki Okrągłego Stołu" uzasadniającej wystąpienia antysystemowe ${ }^{37}$.

Organizacyjnie nurt ten jest reprezentowany przez Narodowe Odrodzenie Polski, lecz mniej więcej od 1994 roku, a także Obóz Narodowo-Radykalny po reorganizacji dokonanej w 2005 roku. Wcześniej natomiast należy tu wymienić takie dość efemeryczne środowiska, jak: Ofensywa Narodowo-Radykalna (Kraków 1993), Front Narodowo-Radykalny (1994), gdańska Polska Partia Narodowa (przed przeistoczeniem się w Związek Orła Białego), a także środowiska ONR Częstochowa i ONR Brzeg, od 2003 roku również Obóz Wielkiej Polski. Do „tradycji” ONR nawiązuje, choć z zastrzeżeniami, organizacja „Falanga” Bartosza Bekiera.

\section{Nurt progresywistyczny}

Nie sposób w niniejszym zestawieniu pominąć nurtu próbującego unowocześnić myśl nacjonalistyczną przy równoczesnej chęci zachowania najcenniejszych elementów dorobku ND. Próby te miały jednak zazwyczaj o wiele słabsze przełożenie na działalność formacyjną. Nie ma bowiem ani jednego podmiotu, w którym nurt ten można by określić jako bezapelacyjnie dominujący. Zazwyczaj towarzyszą mu zatem inne nurty polityczne, nieutożsamiane $\mathrm{z}$ nacjonalizmem, takie jak: konserwatyzm, chadecja czy nurt niepodległościowy. Głównymi elementami „tradycji” tego nurtu są:

1. Nawiązywanie do etosu „Solidarności” - nowa „tradycja” wzbogacająca dotychczasową. Dostrzeganie w „Solidarności” przede wszystkim wielkiego ruchu społecznego o charakterze narodowym i katolickim, nie zaś owocu inspiracji wrogich sił wywrotowych. „Solidarności” jako ruchowi społecznemu przypisywano również przesłanie antykomunistyczne oraz antyliberalne ${ }^{38}$.

2. Nawiązywanie do wczesnej ND z okresu rozbiorów oraz twórczości młodego Dmowskiego. Widać w tym ewidentny wpływ strażników „tradycji” w osobach Wiesława Chrzanowskiego oraz Wojciecha Wasiutyńskiego, a także Albina Tybulewicza ${ }^{39}$. Ceniono zatem dorobek ideowy wczesnej endecji z pominięciem mogącego wzbudzać kontrowersje w szeregach prawicy okresu międzywojennego, w tym zwłaszcza ruchów ekstremistycznych.

36 W latach 90. był on szczególnie wyraźny w publicystyce NOP. A. Gmurczyk, Pod jednym sztandarem do zwycięstwa!, „Awangarda Państwa Narodowego” 1994, nr 5, s. 1; R. Larkowski, Zbrojny idealizm, „Szczerbiec” 1994, nr 9, s. 8; A. Szablak, Przełom, „Pierwsza Linia” 1997, nr 2, s. 4.

37 T. Dorosz, Obalamy mity o O.N.R, „Magna Polonia” 2013, nr 3, s. 67.

38 Program Zjednoczenia Chrześcijańsko-Narodowego, „Głos” 1989, nr 56/57, s. 126.

39 W. Turek, Arka przymierza. Wojciech Wasiutyński 1910-1994. Biografia polityczna, Kraków 2008, s. 387-387; A. Hall, Idee polityczne Wiesława Chrzanowskiego, Gdańsk 2013, s. 28, 31, 55. 
3. Odrzucenie anachronizmów, takich jak antysemityzm, obsesja antymasońska, walka z sanacją ${ }^{40}$. W przypadku sanacji decydowały również względy natury praktycznej, ugrupowania reprezentujące omawiany tu nurt składały się bowiem także z niepodległościowców. W ich miejsce pojawiało się popularne na prawicy w latach 90. XX wieku hasło dekomunizacji, a następnie eliminacji jego mentalnych pozostałości ${ }^{41}$. Utożsamianie się z siłami posierpniowymi w przeciwieństwie do postkomunistycznych stało się jedną $\mathrm{z}$ podstaw tożsamościowych i ideowych tego nurtu jako nurtu prawicowego ${ }^{42}$.

4. Otwarcie się na liberalną demokrację parlamentarną ${ }^{43}$. Ugrupowania reprezentowane przez nurt progresywistyczny startowały z powodzeniem w wyborach parlamentarnych, a nawet wchodziły do koalicji rządowych. Nawiązywały tym samym do parlamentarnych doświadczeń Narodowej Demokracji.

5. Akceptacja głównych tez Kościoła, narodu i państwa Romana Dmowskiego skutkująca sprzeciwem wobec prób separacji tych dwóch instytucji oraz wcielaniem w życie podstaw moralności chrześcijańskiej ${ }^{44}$. W konsekwencji sprzeciwiano się formule państwa neutralnego światopoglądowo lub religijnie. Podejmowano również praktyczne starania o ochronę życia poczętego oraz przywrócenie religii do szkół, a także ochronę moralności publicznej ${ }^{45}$.

Nurt progresywistyczny jest najszerzej reprezentowany przez Zjednoczenie Chrześcijańsko-Narodowe, fragmentarycznie także przez Prawo i Sprawiedliwość. Natomiast jego wcześniejszym inkubatorem, przed 1989 rokiem, był Ruch Młodej Polski, w którym progresywiści tworzyli jeden z najważniejszych kierunków ideowych tego środowiska ${ }^{46}$. Nurt progresywistyczny w dużej części koresponduje z myślą narodową lub katolicko-narodową.

\section{Nurt neopogańsko-słowiański}

Jak dotąd mieliśmy do czynienia z przejawami myśli politycznej i ruchów w większości dających się zaliczyć do nacjonalizmu chrześcijańskiego w ujęciu zaprezentowanym przez Bogumiła Grotta. Inną jakość stanowi nurt neopogańsko-słowiański, w obrębie którego mieszczą się organizacje i osoby, które o wiele łatwiej można zaliczyć do wyodrębnionych przez tego autora nacjonalizmów: pogańskiego, a także laickiego. Rolę

40 W. Turek, op. cit., s. 426.

41 M. Jurek, Długi cień komunizmu, „Nasz Dziennik” 2001, nr 51, s. 12; idem, Neokomunizm przeciw wdzięczności i pamięci, „Nasz Dziennik” 2001, nr 69, s. 11. Zob. W. Nawrocki, Zjednoczenie Chrześcijańsko-Narodowe, „Dziś” 1992, nr 9, s. 52-62.

42 Uchwały Rady Naczelnej Zjednoczenia Chrześcijańsko-Narodowego z dnia 10 lutego 1996, Pracownia Dokumentacji i Badań Życia Politycznego, 13981/96/1196, s. 19.

43 Program Zjednoczenia Chrześcijańsko-Narodowego..., s. 127.

44 A. Hall, op. cit., s. 40.

45 R. Czarnecki, Nasz patriotyzm - dzisiaj, Warszawa 1992, b.n.s.; R. Graczyk, Chrzanowski, Warszawa 2013, s. 271; Program Zjednoczenia Chrześcijańsko-Narodowego..., s. 127.

46 Szerzej na ten temat piszą m.in.: T. Sikorski, O kształt polityki polskiej. Oblicze ideowo-polityczne i działalność Ruchu Młodej Polski, Toruń 2011; P. Zaremba, Młodopolacy. Historia Ruchu Młodej Polski, Gdańsk 2000. 
podstawowego zwornika obydwu nacjonalizmów odgrywa „tradycja” przedwojennej Zadrugi. Charakterystyczne są tu takie jej elementy, jak:

1. Daleko posunięta niechęć do katolicyzmu przechodząca nieraz w antyklerykalizm. Jest to trzon "tradycji” myśli odziedziczonej po Janie Stachniuku, wynikający z przekonania o negatywnej roli katolicyzmu w dziejach Polski ${ }^{47}$.

2. Podważanie wagi kultury polskiej związanej z katolicyzmem i próby szukania jej substytutu. Katolicyzm i pochodząca z niego kultura miały hamować rozwój cywilizacyjny narodów katolickich w Europie i pełnić funkcję tak zwanej wspakkultury, a zatem destruktywnego światopoglądu, powstrzymującego „ewolucję tworzycielską świata”, promującego bierność i apatięe ${ }^{48}$. W miejsce katolicyzmu pojawia się przedchrześcijańska obrzędowość, a nawet wierzenia.

3. Sięganie do słowiańskich i indoeuropejskich źródeł kultury. Jest to kontynuacja koncepcji „nadnarodu” Stachniuka, która pojawiła się w późniejszym okresie jego twórczości. W myśli politycznej i publicystyce środowisk i ugrupowań nurtu neopogańsko-słowiańskiego gości zatem motyw współpracy i koniecznych bliskich związków Polski i Polaków z innymi narodami słowiańskimi ${ }^{49}$.

4. Elementy rasistowskie, nieobecne wcześniej w ideologii Jana Stachniuka, krytykował on bowiem teorie wiążące polski charakter narodowy $\mathrm{z}$ rasą, a nawet pochwalał mieszanie się ras, tym samym dezawuował rasizm ${ }^{50}$. Tymczasem niektóre środowiska odwołujące się od „tradycji” zadrużnej uznają rasizm za „najdoskonalszą formę miłości”. Propaguje się również czystość rasową ${ }^{51}$.

5. Odrzucenie kolektywizmu i planowości w gospodarce - obecnych w ideologii Stachniuka. Niniejsza innowacja została dokonana już przez Antoniego Wacyka w obliczu radykalnej zmiany warunków społeczno-politycznych po 1989 roku i jest kontynuowana przez innych przedstawicieli nurtu ${ }^{52}$. Dostrzegalna staje się zatem w tym wypadku istotna rola innowacyjna strażników „tradycji”.

Do podmiotów organizacyjnych wchodzących w skład nurtu słowiańsko-neopogańskiego po 1989 roku można zaliczyć: Narodowy Zespół Koncepcyjno-Studyjny z pismem „Żywioł” (a wcześniej Polski Front Narodowy z biuletynem „Świadomość”), Unię Społeczno-Narodową, Stowarzyszenie na Rzecz Tradycji i Kultury „Niklot” z pismem „Trygław”, Nacjonalistyczne Stowarzyszenie „Zadruga”, a także pośrednio takie partie polityczne, jak Polska Wspólnota Narodowa. Można też wymienić środowiska i pisma z pogranicza rodzimowierstwa, jak: Zrzeszenie Rodzimej Wiary, „Odala”, „Odmrocze”,

47 Na przykład A. Wacyk, Na pohybel katolictwu, Wrocław 1995; idem, O polski charakter narodowy, Wrocław 1995. Krytyka religii monoteistycznych i chrześcijaństwa (czyt. antyklerykalizm) jest jednym z najczęstszych motywów w spokrewnionych z powyższym nurtem czasopismach rodzimowierczych. R. Okraska, W kręgu Odyna i Trygław. Neopoganizm w Polsce i na świecie (zarys problematyki), Biała Podlaska 2001, s. 90.

${ }^{48}$ J. Stachniuk, Chrześcijaństwo a ludzkość, Wrocław 1997, s. 21.

49 B. Tejkowski, W obronie Polski, w obronie słowiańszczyzny, Warszawa 2011, s. 173.

50 J. Stachniuk, Dzieje bez dziejów, Wrocław 1990, s. 41; idem, Mit słowiański, Wrocław 2006, s. 85.

${ }^{51} \mathrm{Na}$ przykład $W$ imię rasy $i$ krwi, http://ns-zadruga.blogspot.com/2007/07/w-imi-rasy-i-krwi.html (dostęp: 13.03.2014).

52 B. Grott, Religia, cywilizacja, rozwój..., s. 298. 
portal „Sędruga”. Należy podkreślić, że dokonanie czytelnego rozróżnienia środowisk zadrużnych (kulturowo-politycznych) od rodzimowierczych, a zatem przede wszystkim religijnych, nie należy do zadań łatwych. Nie ułatwia tego ponadto częstokroć deklarowana metapolityczność tych środowisk ${ }^{53}$.

\section{Podsumowanie}

Zaprezentowany tu podział ma charakter modelowy, toteż jest obarczony ryzykiem błędu. Wymienione elementy „tradycji” nie muszą zatem sprawdzać się w stu procentach. „Tradycja” rozumiana jednak jako rodzaj refleksyjnego i świadomego wyboru dorobku przeszłości może stanowić kategorię dywersyfikującą myśl nacjonalistyczną, a zarazem tworzącą czytelne i ponadkoniunkturalne różnice ideowe pomiędzy poszczególnymi podmiotami politycznymi. Bardzo istotną rolę w dokonywaniu owego wyboru odgrywają osoby odpowiedzialne za transmisję międzypokoleniową, innymi słowy: strażnicy „tradycji”. W przypadku ruchu narodowego w Polsce „tradycja” nie ogranicza się jednak do samego tylko obszaru myśli politycznej, lecz obejmuje także historię ruchu narodowego, jego symbolikę oraz wiele innych obszarów wpisanych w „tradycję” po 1989 roku.

Kategoria „tradycji” pozwala na wyodrębnienie kilku cech charakterystycznych zespalających dany nurt, niezależnie od bieżących relacji politycznych, jakie występują pomiędzy reprezentującymi je podmiotami. Przykładem mogą być relacje między ONR a Narodowym Odrodzeniem Polski czy też wcześniej SN „Senioralnym” a Stronnictwem Narodowo-Demokratycznym. „Tradycja” pozwala też na abstrahowanie od stosunku do ogniskujących opinię środowisk narodowych po 1989 roku problemów politycznych, jak stosunek do religii i Kościoła katolickiego, integracji europejskiej, NATO, prywatyzacji, globalizacji, ideologii pooświeceniowych czy wreszcie sąsiadów Polski. Kategoria „tradycji” pozwala także na uniezależnienie się od tych kanonów myśli nacjonalistycznej, które przynajmniej na pierwszy rzut oka wydają się spajać przedstawicieli ugrupowań nacjonalistycznych, takich jak naród i państwo.

\section{Bibliografia}

Chodakiewicz M.J., Mysiakowska-Muszyńska J., Muszyński W.J., Polska dla Polaków! Kim byli i są polscy narodowcy, Zysk i S-ka, Poznań 2015.

Czarnecki R., Nasz patriotyzm — dzisiaj, Zarząd Główny ZChN, Warszawa 1992.

Deklaracja Ideowo-Programowa Ofensywy Narodowo-Radykalnej, „Błyskawica” 1993, nr 8.

Engelgard J., Testament Dmowskiego. Niemcy - Rosja - Polska, Wydawnictwo Polskie, Warszawa 1996.

Epigoństwo czy twórcza ciagłość? Ideowe dziedzictwo głównych nutów politycznych Drugiej Rzeczypospolitej po zakończeniu II wojny światowej, red. E. Krasucki, T. Sikorski, A. Wątor, Adam Marszałek, Toruń 2011. Gellner E., Narody i nacjonalizm, przeł. A. Grzybek, Wydawnictwo Naukowe PWN, Warszawa 1991.

53 Taka deklaracja widnieje na przykład w podtytule pisma „Trygław”. Do działań o charakterze metapolitycznym przyznają się również wrocławskie środowiska zadrużan. 
Giddens A., Życie w społeczeństwie posttradycyjnym, [w:] Modernizacja refleksyjna, red. U. Beck, A. Giddens, S. Lash, przeł. J. Konieczny, Wydawnictwo Naukowe PWN, Warszawa 2009.

Giertych M., Dmowski czy Piłsudski?, Nortom, Wrocław 1995.

Giertych R., Kontrrewolucja młodych, Ad Astra, Warszawa 1994.

Graczyk R., Chrzanowski, Świat Książki, Warszawa 2013.

Greniuch T., Droga nacjonalisty, Michał Olszewski, Opole 2013.

Grott B., Nacjonalizm czy nacjonalizmy (zamiast wstępu), [w:] Nacjonalizm czy nacjonalizmy? Funkcja wartości chrześcijańskich, świeckich i neopogańskich w kształtowaniu idei nacjonalistycznych, red. B. Grott, Nomos, Kraków 2006.

Grott B., Religia, cywilizacja, rozwój. Wokół idei Jana Stachniuka, Nomos, Kraków 2003.

Hall A., Idee polityczne Wiesława Chrzanowskiego, Arche, Gdańsk 2013.

Hayes C.J.H., The Historical Evolution of Modern Nationalism, Richard R. Smith Inc., New York 1931.

Hervieu-Léger D., Religia jako pamięć, przeł. M. Bielawska, Nomos, Kraków 2007.

Jackowski J.M., Bitwa o prawdę, t. III, Ad Astra, Warszawa 1997.

Jaroszyński P., Kim jesteśmy, Instytut Edukacji Narodowej, Lublin 2001.

Jaroszyński P., Suwerenność nie jest przeżytkiem!, Instytut Edukacji Narodowej, Lublin 2000.

Kohn H., The Idea of Nationalism. A Study in Its Origins and Background, Macmillan Company, New York 1944.

Koneczny F., Polskie logos a ethos. Roztrząsanie o znaczeniu i celu Polski, t. I, Księgarnia św. Wojciecha, Poznań 1921.

Łętocha R., Idee dystrybucjonistyczne w pogladach społeczno-gospodarczych młodego pokolenia obozu narodowego, [w:] Europejskie inspiracje myśli politycznej w Polsce od XIX wieku. Recepcja - kontynuacja interpretacja, red. E. Maj et al., Wydawnictwo UMCS, Lublin 2013.

Maj C., Maj E., Narodowe ugrupowania polityczne w Polsce 1989-2001, Wydawnictwo UMCS, Lublin 2007.

Maj E., Komunikowanie polityczne Narodowej Demokracji 1918-1939, Wydawnictwo UMCS, Lublin 2010.

Maj E., Myśl Narodowa i nacjonalistyczna, [w:] Myśl polityczna w Polsce po 1989 roku. Wybrane nurty ideowe, red. E. Maj, A. Wójcik, Wydawnictwo UMCS, Lublin 2008.

Maj E., Wielonurtowość myśli nacjonalistycznej w Polsce współczesnej, [w:] Idee w procesie kształtowania współczesnej rzeczywistości polskiej. Nacjonalizm, red. E. Maj, M. Mikołajczak, M. Śliwa, Wydawnictwo Naukowe Uniwersytetu Pedagogicznego, Kraków 2010.

Meller A., Myśl polityczna Narodowego Odrodzenia Polski w latach 1994-2004 - epigoństwo czy twórcze rozwinięcie dziedzictwa międzywojennych narodowych radykałów?, [w:] W kręgu Odyna i Trygława. Neopoganizm w Polsce i na świecie (zarys problematyki), red. R. Okraska, Rekonkwista, Biała Podlaska 2001.

Miner B., Zwięzła encyklopedia konserwatyzmu, przeł. T. Biedroń, Zysk i S-ka, Poznań 1999.

Pracownia Dokumentacji i Badań Życia Politycznego przy Instytucie Politologii Uniwersytetu Wrocławskiego

Scrurton R., Co znaczy konserwatyzm, przeł. T. Biedroń, Zysk i S-ka, Poznań 2002.

Shils E., Tradition, „Comparative Studies in Society and History” 13, 1971, nr 2.

Sikorski T., Miejsce antydemokratyzmu w publicystyce politycznej Narodowego Odrodzenia Polski, [w:] Narodowa Demokracja XIX-XX wiek (Koncepcje - Ludzie - Działalność), red. T. Sikorski, A. Wątor, ZAPOL, Szczecin 2008.

Stachniuk J., Chrześcijaństwo a ludzkość, Toporzeł, Wrocław 1997.

Stachniuk J., Mit słowiański, Toporzeł, Wrocław 2006.

Strutyński M., Religia i naród. Inspiracje katolickie w myśli ruchu narodowego w Polsce wspótczesnej (19892001), Nomos, Kraków 2006.

Szacki J., Tradycja. Wydanie II rozszerzone, Wydawnictwo Uniwersytetu Warszawskiego, Warszawa 2011.

Tejkowski B., W obronie Polski, w obronie słowiańszczyzny, Polska Wspólnota Narodowa, Warszawa 2011.

Tomasiewicz J., Ugrupowania neoendeckie w III Rzeczypospolitej, Adam Marszałek, Toruń 2003.

Turek W., Arka przymierza. Wojciech Wasiutyński 1910-1994. Biografia polityczna, Acana, Kraków 2008.

Uchwały Rady Naczelnej Zjednoczenia Chrześcijańsko-Narodowego z dnia 10 lutego 1996, Pracownia Dokumentacji i Badań Życia Politycznego, 13981/96/1196. 
Wacyk A., Na pohybel katolictwu, Toporzeł, Wrocław 1995.

Wacyk A., O polski charakter narodowy, Toporzeł, Wrocław 1995.

Winnicki R. et al., Kto się boi ruchu narodowego, Bollinari Publishing House, Warszawa 2013.

Wprowadzenie w program i założenia ideowe FNR-ONR, „Sztafeta” 1995, nr 1/3.

Zaremba P., Młodopolacy. Historia Ruchu Młodej Polski, Arche, Gdańsk 2000.

Żmigrodzki Z., Akcje antynarodowe, Nortom, Wrocław 2005.

Żmigrodzki Z., Meandry nowej wiary, czyli inwazja katolewicy, Antyk — Marcin Dybowski, Komorów 1998.

\section{Źródła internetowe}

Dlaczego warto wstapić do ONR, http://www.onr.com.pl/dlaczego.html.

Holocher P., Giertychów logika przedziwna, http://prawy.pl/index.php?option=com_content\&view=article \&id=2333:giertychow-logika-przedziwna\&catid=58:felieton.

O nas, http://www.onr.com.pl/index.html.

W imię rasy $i$ krwi, http://ns-zadruga.blogspot.com/2007/07/w-imi-rasy-i-krwi.html.

\section{Contemporary currents of the Polish nationalist thought - an attempt at division in terms of the category of "tradition"}

Keywords: tradition, nationalism, political thought, political currents

\section{Summary}

This article aims at outlining the method of dividing the Polish political thought. For this purpose the category of "tradition" is used. "Tradition" is perceived by the author as a type of conscious and reflective choice of achievements of the past made in the present. Based on "tradition" the author distinguishes the following currents of the Polish nationalist thought: the current of Neo-National Democracy, the current of National Radicalism, the Catholic National current, as well as the Progressive current and the current of Slavonic Neo-Paganism. Apart from political thought the tradition of Polish nationalism also includes political movement issues, literature and art. An important role in the reception and transmission of "tradition" to contemporary times is played by its guardians, which means people who endeavor to pass it on in a form desired by them. 